\title{
Lixisenatide: evidence for its potential use in the treatment of type 2 diabetes
}

This article was published in the following Dove Press journal:

Core Evidence

7 September 2011

Number of times this article has been viewed

\section{Anthony H Barnett \\ University of Birmingham and BioMedical Research Centre, Heart of England National Health Service Foundation Trust, Birmingham, UK}

Correspondence: Anthony H Barnett Diabetes Centre, Birmingham Heartlands Hospital, Bordesley Green East,

Birmingham, B9 5SS, UK

Tel +44 0 I 2 I424 3587

Fax +44 012 I424 0593

Email anthony.barnett@heartofengland. nhs.uk
Abstract: Lixisenatide is a once-daily glucagon-like peptide 1 (GLP-1) receptor agonist mimicking several favorable actions of endogenous GLP-1 that result in improved glycemic control with little or no hypoglycemia and weight loss. Phase II trials have shown that lixisenatide $20 \mu \mathrm{g}$ once daily restores first-phase insulin release in patients with type 2 diabetes and improves the second-phase insulin response. Administered once or twice daily for 4 weeks, it significantly reduced postprandial and fasting blood glucose levels, and glycosylated hemoglobin $\left(\mathrm{HbA}_{1 \mathrm{c}}\right)$. The efficacy and safety of lixisenatide once daily is being assessed in the GETGOAL Phase III clinical trial program. Results have shown beneficial effects on $\mathrm{HbA}_{1 \mathrm{c}}$ compared with placebo in combination with commonly used antidiabetes agents, with no increased risk of hypoglycemia and with beneficial weight reduction. Adverse effects were similar to those observed for available GLP-1 receptor agonists, the most frequent being gastrointestinal. Both GLP-1 receptor agonists and long-acting insulin analogs have demonstrated protective effects on beta cells in preclinical studies. This, along with the pronounced effect of lixisenatide on postprandial plasma glucose, provides a rationale for combining it with long-acting basal insulin analogs, in the hope that the additive effects on glycemic control combined with a potential benefit on islet cells may lead to a new treatment approach to control blood glucose better and prevent long-term complications in patients with type 2 diabetes.

Keywords: GLP-1 receptor agonist, combination therapy, GETGOAL program, insulin, lixisenatide, postprandial plasma glucose, type 2 diabetes

\section{Core Evidence clinical impact summary for lixisenatide in type 2 diabetes}

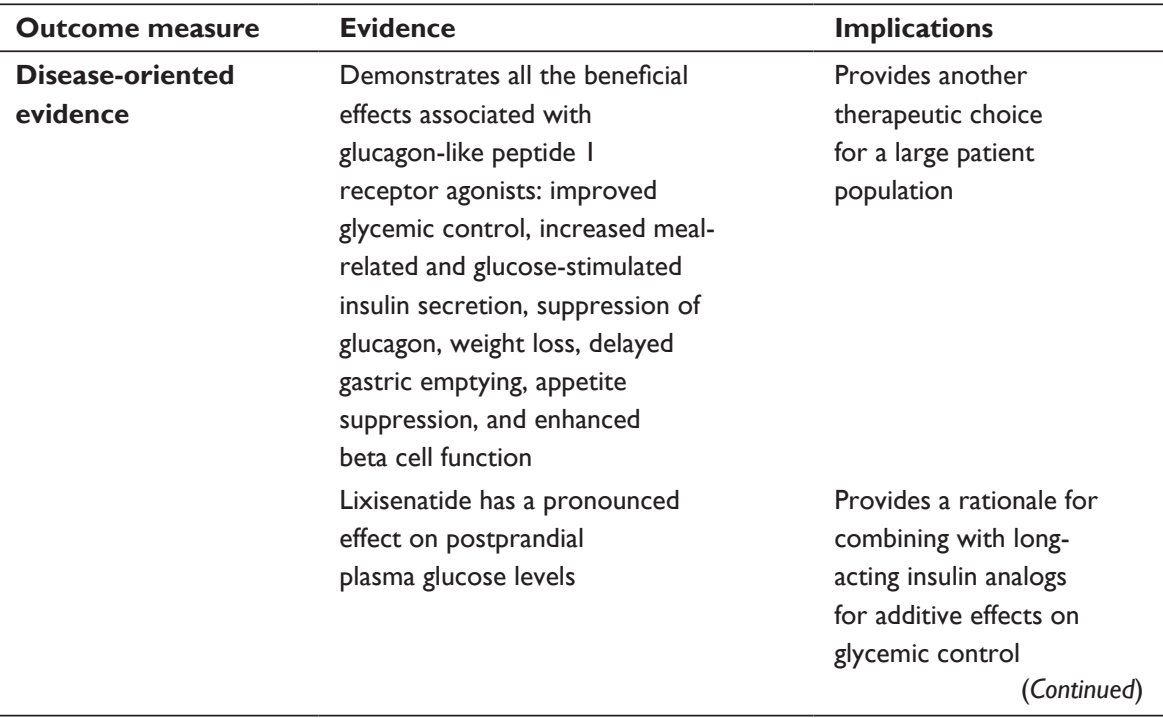




\begin{tabular}{|lll|}
\hline $\begin{array}{l}\text { (Continued) } \\
\text { Outcome measure }\end{array}$ & Evidence & Implications \\
\hline $\begin{array}{l}\text { Patient-oriented evidence } \\
\text { Hypoglycemia }\end{array}$ & Low risk of hypoglycemia in & If approved, lixisenatide may \\
& combination with insulin & offer an alternative in patients \\
Gastrointestinal adverse events & Nausea is the most frequent & in whom hypoglycemia must \\
& adverse event similar to & be avoided or weight loss is \\
& other glucagon-like peptide I & important \\
& receptor agonists & \\
Beneficial weight loss has been & \\
& observed with lixisenatide & \\
\hline
\end{tabular}

\section{Introduction}

Worldwide, the type 2 diabetes epidemic continues to expand and exert socioeconomic strain on national health care systems. ${ }^{1}$ Statistics from the UK indicate that around $10 \%$ of National Health Service spending is on diabetes and its complications, which equates to $£ 9$ billion. ${ }^{2}$ Although there is a wide variation in prevalence by European country, the total number of adults with diabetes in the region was predicted to reach 55.2 million by 2010 , accounting for $8.5 \%$ of the adult population. ${ }^{3}$

In the UK, as in other countries, the prevalence of type 2 diabetes is increasing and varies with factors including age, ethnic group, and social deprivation. Quality and Outcomes Framework data, which provide information on people 17 years of age and older with type 2 diabetes registered with general practices, indicate that during the period April 2009 to March 2010, the number of people diagnosed in England increased by more than 125,000 on the previous year, resulting in a UK prevalence of $5.4 \% .^{4}$ The true prevalence will be far higher than this because this figure does not include the estimated 1.1 million people in the UK with undiagnosed type 2 diabetes. These disturbing figures illustrate the importance of preventing type 2 diabetes, and helping those who do have the disease to manage it to prevent serious complications, such as renal failure, diabetic retinopathy, amputation, and cardiovascular disease.

The past decade has seen considerable progress in our understanding of the pathogenetic mechanisms involved in the progression of the disease. The treatment of type 2 diabetes has taken advantage of these scientific advances and resulted in several new therapies coming to the market. Some of the most important developments in this area surround glucagon-like peptide 1 (GLP-1), a naturally occurring peptide that is released from the gut within minutes of eating a meal. ${ }^{5}$ GLP-1 possesses a number of properties that make it a potentially ideal antidiabetes agent, including glucose-dependent insulin secretion, inhibition of glucagon secretion, delayed gastric emptying, and promotion of satiety.
In addition, direct effects on beta-cell growth and survival have been identified. ${ }^{5}$

Two therapeutic strategies have been developed to take advantage of these actions. The first is to use GLP-1 receptor agonists, which have a substantially longer half-life than GLP-1 due to reduced degradation by the dipeptidyl peptidase 4 (DPP-4) enzyme. Exenatide and liraglutide are the two currently available GLP-1 receptor agonists. The second strategy is to inhibit DPP-4, which prolongs the half-life of endogenously released GLP-1 and has led to the development of the DPP-4 inhibitors. Both strategies have proved very successful and the use of these agents as add-on treatment for type 2 diabetes is endorsed by the National Institute for Health and Clinical Excellence, ${ }^{6}$ the European Association for the Study of Diabetes, ${ }^{7}$ and the American Diabetes Association, ${ }^{8}$ among others.

GLP-1 also has a number of favorable effects for patients with type 2 diabetes beyond its benefits on glucose control. For example, agents that activate the GLP-1 receptor improve glucose tolerance alongside a low risk of hypoglycemia, beneficial weight loss, and have the potential to modify disease progression. ${ }^{5}$ The diverse actions of this class, and their novel and complementary mechanism of action, make them an appealing addition to the current therapeutic options for treating type 2 diabetes and significant research is ongoing in this field. The latest agent to reach Phase III clinical trials is the GLP-1 receptor agonist, lixisenatide. To provide the most up to date information on this agent, the Clinicaltrials.gov registry was first searched to identify all relevant clinical trials, then conference abstracts, and Medline were searched to obtain all published articles. This review summarizes all the available published evidence for lixisenatide up to the end of June 2011.

\section{Lixisenatide: a new GLP-I receptor agonist}

The very short half-life of endogenous GLP- $1^{9}$ has led to extensive research to find new compounds with pharmacokinetic properties suitable for development of a 
pharmaceutical agent. Exendin-4 was first isolated from the salivary gland of the Gila monster (Heloderma suspectum), and characterization showed that the peptide was structurally related to but distinct from GLP-1, with a sequence homology of 53\%. ${ }^{9}$ Exendin-4 is a potent agonist for the mammalian GLP-1 receptor with a longer in vivo half-life, prolonged duration of action, and GLP-mimetic actions.

Lixisenatide (also known as AVE0010 and ZP10) is a GLP-1 receptor agonist in late-stage development. In 2003, Zealand Pharma outlicensed lixisenatide to Sanofi-Aventis who is now responsible for all further clinical development. Like exenatide, lixisenatide is a synthetic version of exendin-4. It is able to withstand physiological degradation by DPP-4 as a result of C-terminal modification with six lysine residues and deletion of one proline (Figure 1). The half-life of lixisenatide is $2-4$ hours, and it is classed as a short-acting GLP-1-receptor agonist, compared with the long-acting GLP-1-based peptides, liraglutide and albiglutide. Despite its relatively short half-life, lixisenatide is intended for once-daily dosing as a result of its strong binding affinity to the GLP-1 receptor. Receptor binding studies have shown that the median inhibitory concentration $\left(\mathrm{IC}_{50}\right)$ of lixisenatide for the human GLP-1 receptor is $1.4 \mathrm{nM}$, which is approximately four-fold greater than the affinity of GLP- $1 .{ }^{10}$ In contrast, liraglutide has been shown to displace radiolabeled GLP-1 from human GLP-1 receptors with an $\mathrm{IC}_{50}$ of $0.11 \mathrm{nM}$, compared with values of $0.35 \mathrm{nM}$ for GLP-1 and $0.55 \mathrm{nM}$ for exenatide.

\section{Preclinical findings}

The preclinical pharmacological profile of lixisenatide demonstrates a number of important acute and longer-term actions that are highly relevant to the maintenance of glucose homeostasis. A detailed review of the preclinical pharmacological profile of lixisenatide is provided by Werner et $\mathrm{al}^{11}$ and is only briefly summarized here.

\section{Effects on glucose-stimulated insulin secretion}

The beneficial effects of lixisenatide on glycemic control have been demonstrated in both healthy animals and in animal models of type 2 diabetes. In isolated pancreas from healthy Wistar rats, lixisenatide significantly improved glucose-stimulated insulin secretion compared with saline control after a switch to high glucose concentrations. The effect of lixisenatide on insulin secretion was greater than that observed with GLP-1, consistent with the greater affinity reported for lixisenatide at the GLP-1 receptor. ${ }^{12}$

When fed a lipid-rich diet, the inherited obesity gene mutation of the Zucker Diabetic Fatty (ZDF) rat provides us with an animal model that mimics human adult onset type 2 diabetes and its related complications. A continuous subcutaneous infusion of lixisenatide $50 \mu \mathrm{g} / \mathrm{kg} /$ day for 6 weeks to ZDF rats preserved both first-phase and second-phase glucose-stimulated insulin secretion and total insulin secretion, whereas untreated rats showed a progressive impairment of insulin secretion and loss of the biphasic pattern of insulin secretion during the development of type 2 diabetes. ${ }^{12}$ Treated ZDF rats also demonstrated a suppression of glucagon secretion in response to high glucose concentrations.

\section{Effects on blood glucose levels}

In healthy normoglycemic dogs, single subcutaneous injections of lixisenatide produced dose-dependent reductions in plasma glucose after an oral glucose challenge and significantly reduced postprandial glucose excursions by $67 \%$ compared with placebo without increasing insulin concentrations. ${ }^{13}$ Using absorption of paracetamol as a measure of gastric emptying, the researchers observed that lixisenatide significantly reduced arterial plasma paracetamol concentration by $53 \%$ versus placebo, suggesting that the effect of lixisenatide on postprandial blood glucose excursions in dogs is, at least in part, related to inhibition of gastric emptying and delayed intestinal glucose absorption. ${ }^{13}$

Dose-dependent reductions in plasma glucose after an oral glucose challenge have been demonstrated in both the $d b / d b$ mouse and ZDF rat, ${ }^{10,14}$ two rodent models of diabetes in which mutations in the leptin receptor gene result in obesity and insulin resistance. Importantly, this activity was glucose-dependent with no effect at physiological glucose concentrations. Although the lack of effective leptin signaling

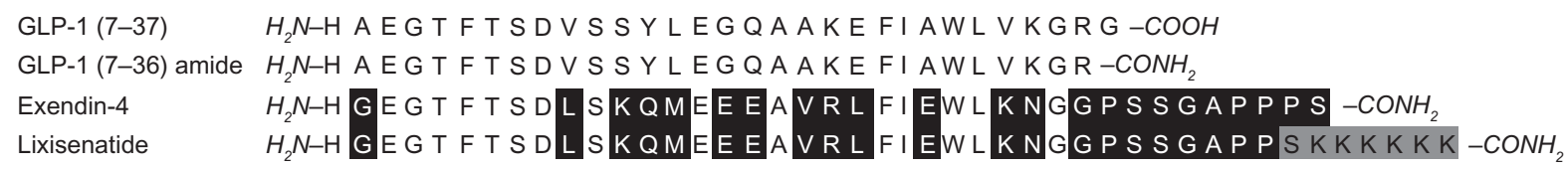

Figure I Structure of lixisenatide. The amino acid sequence of lixisenatide is shown alongside that of exendin-4 and pharmacologically active forms of human glucagon-like peptide I. Amino acids highlighted in black show elements of lixisenatide or exendin-4 that differ from human glucagon-like peptide I. Amino acids highlighted in gray show elements unique to lixisenatide.'

Abbreviation: GLP-I, glucagon-like peptide I.

Note: Reprinted from Regulatory Peptides, Vol 164, U Werner, H Haschke, AW Herling, W Kramer, Pharmacological profile of lixisenatide: A new GLP-I receptor agonist for the treatment of type 2 diabetes, Pages 58-64, Copyright 2010, with permission from Elsevier. 
in $d b / d b$ mice and ZDF rats promotes the development of diabetes via mechanisms that do not commonly occur in most human patients with type 2 diabetes, these animal models have contributed substantially to our understanding of the pathophysiology and treatment of type 2 diabetes and its complications. In $d b / d b$ mice, chronic lixisenatide administration prevented the progressive deterioration in glucose tolerance observed in control animals and was associated with significant dose-dependent reductions in glycosylated hemoglobin $\left(\mathrm{HbA}_{1 \mathrm{c}}\right) \cdot{ }^{10}$ In $\mathrm{ZDF}$ rats, a continuous subcutaneous infusion of lixisenatide $50 \mu \mathrm{g} / \mathrm{kg} /$ day for 12 weeks significantly decreased basal blood glucose and improved oral glucose tolerance compared with control animals. ${ }^{14}$ At the end of the study, there was also a significant $1.7 \%$ reduction in $\mathrm{HbA}_{1 \mathrm{c}}$ compared with controls. Lixisenatide had no hypoglycemic effect and did not change $\mathrm{HbA}_{1 \mathrm{c}}$ in normoglycemic rats.

\section{Effects on beta cell function}

There is also evidence from animal studies that lixisenatide can maintain beta cell mass and function through stimulation of islet cell proliferation and neogenesis, and inhibition of islet cell apoptosis. In two experiments in the $d b / d b$ mouse model of diabetes in which animals were treated chronically with intraperitoneal administration of lixisenatide up to $500 \mu \mathrm{g} / \mathrm{kg}$ or control, lixisenatide preserved pancreatic insulin mRNA expression and was associated with a dosedependent increase in beta cell mass. ${ }^{10}$

The effects of lixisenatide on beta cell function have also been evaluated using pancreatic islets isolated from eight post mortem subjects who did not have type 2 diabetes. ${ }^{15}$ The islets were cultured either acutely ( 1 hour) under physiological conditions at low $(2.8 \mathrm{mmol} / \mathrm{L})$ or high $(20 \mathrm{mmol} / \mathrm{L})$ glucose concentrations, or chronically (48 hours) under lipotoxic conditions, followed by a 1-hour incubation at low or high glucose concentrations. Under physiological conditions, lixisenatide dose-dependently increased glucosestimulated insulin secretion in human islets to a greater degree than GLP-1. Chronic lipotoxic stress conditions led to increases in triglyceride content, decreases in insulin content, and reductions in glucose-stimulated insulin secretion in untreated human islets. Although lixisenatide and GLP-1 had no effect on triglyceride content, both peptides were able to prevent lipid-induced insulin depletion. Moreover, lixisenatide and GLP-1 were able to preserve the beta-cell response to glucose in human islets.

In vitro studies using the INS-1 rat pancreatic beta cell line have shown that lixisenatide protects beta cells against lipid-induced and cytokine-induced apoptosis in the order of $50 \%-60 \% .{ }^{16}$ Similar findings have been observed when beta cells are pretreated with several different rapid-acting or long-acting insulin analogs, and combined treatment of cells with lixisenatide and the long-acting analog, insulin glargine, has revealed additive activity and the prevention of both cytokine-induced and free fatty acid-induced apoptosis by up to $80 \%$. These early findings are now being evaluated in clinical trials to determine whether the combination of a GLP-1 receptor agonist, such as lixisenatide, and insulin glargine might represent an effective strategy for preserving beta cell mass in patients with type 2 diabetes.

\section{Pharmacokinetic and pharmacodynamic studies}

Two lixisenatide trials have determined the dose-response effect and successfully demonstrated the restoration of insulin release in patients with type 2 diabetes taking oral antidiabetes agents. ${ }^{17,18}$ In a 4-week study, the pharmacokinetics and pharmacodynamics of stepwise increasing doses of lixisenatide were examined in 64 patients with type 2 diabetes $\left(\mathrm{HbA}_{1 \mathrm{c}} \geq 7.0 \%\right.$ to $\left.\leq 10.0 \%\right) .{ }^{17}$ Patients were randomized to one of three treatment arms, ie, lixisenatide once daily ( $5 \mu \mathrm{g}$ in the morning with volume-matched placebo in the evening), lixisenatide twice daily ( $5 \mu \mathrm{g}$ in the morning and $5 \mu \mathrm{g}$ in the evening), or volume-matched placebo in the morning and evening. The lixisenatide treatment was increased, based on tolerability, every fifth day in increments of $2.5 \mu \mathrm{g}$ to a maximum dose of $20 \mu \mathrm{g}$ per injection (ie, $20 \mu \mathrm{g}$ in the oncedaily arm and $40 \mu \mathrm{g}$ in the twice-daily arm). Patients were on a stable treatment with metformin and/or sulfonylurea, which was maintained throughout the study.

Lixisenatide concentrations increased in a dose-dependent manner, reaching peak concentrations between one and two hours (Table 1). ${ }^{17}$ At each dose level $(5 \mu \mathrm{g}, 10 \mu \mathrm{g}$, and $20 \mu \mathrm{g}$ ) the morning steady-state plasma concentration profiles were similar for the once-daily and twice-daily lixisenatide treatment groups. Mean area under the concentration-time curve (AUC) and peak plasma concentration $\left(\mathrm{C}_{\max }\right)$ increased according to the dose and dose frequency of lixisenatide (Table 1). Comparisons of lixisenatide doses $(5 \mu \mathrm{g}, 10 \mu \mathrm{g}$, and $20 \mu \mathrm{g})$ demonstrated significantly greater AUC h.pg/mL values for the $20 \mu \mathrm{g}$ group compared with all other treatment groups (Table 1).

At doses of 5-20 $\mu \mathrm{g}$, both the once-daily and twice-daily lixisenatide treatment regimens were associated with statistically significant improvements in the primary endpoint of change in the AUC for postprandial blood glucose after a standardized test meal on day 28. The greatest reductions in postprandial blood glucose compared with placebo were seen 
Table I Pharmacokinetic results from a study of 64 patients with type 2 diabetes randomized to lixisenatide once-daily or twice-daily, or placebo for 28 days. Results are for the 24-hour measurement period performed on days 4, 12, and $28^{17}$

\begin{tabular}{|c|c|c|c|c|c|c|}
\hline \multirow[t]{2}{*}{ Variable } & \multicolumn{2}{|l|}{ Day $4(5 \mu \mathrm{g})$} & \multicolumn{2}{|l|}{ Day $12(10 \mu \mathrm{g})$} & \multicolumn{2}{|l|}{ Day $28(20 \mu \mathrm{g})$} \\
\hline & $\begin{array}{l}\text { Lixisenatide } \\
\text { I } \times / \text { day }(n=8)\end{array}$ & $\begin{array}{l}\text { Lixisenatide } \\
2 \times / \text { day }(\mathrm{n}=\mathrm{II})\end{array}$ & $\begin{array}{l}\text { Lixisenatide } \\
\text { I } \times / \text { day }(n=9)\end{array}$ & $\begin{array}{l}\text { Lixisenatide } \\
2 \times / \text { day }(n=I I)\end{array}$ & $\begin{array}{l}\text { Lixisenatide } \\
\text { I } \times / \text { day }(n=9)\end{array}$ & $\begin{array}{l}\text { Lixisenatide } \\
2 \times / \text { day }(n=I I)\end{array}$ \\
\hline $\begin{array}{l}\mathrm{AUC} h \cdot \mathrm{hg} / \mathrm{mL} \\
(\text { mean } \pm \mathrm{SD})\end{array}$ & $267.6 \pm 130$ & $512.6 \pm 152$ & $420.5 \pm 178$ & $916.0 \pm 249$ & $847.8 \pm 337$ & $1788.6 \pm 709$ \\
\hline $\begin{array}{l}C_{\text {max }}, p g / m L \\
(m e a n \pm S D)\end{array}$ & $37.3 \pm 12$ & $50.9 \pm 17$ & $82.7 \pm 37$ & $108.6 \pm 24$ & $187.2 \pm 70$ & $234.4 \pm 90$ \\
\hline $\mathrm{t}_{\max }, \mathrm{h}$ (median) & 1.25 & 2.25 & 1.25 & 2.25 & 1.25 & 1.25 \\
\hline $\mathrm{T}_{1 / 2}, \mathrm{~h}$ (median) & 3.4 & 4.3 & 2.7 & 3.1 & 2.8 & 3.2 \\
\hline
\end{tabular}

Abbreviations: AUC, area under the concentration-time curve; $S D$, standard deviation; $t_{\text {max }}$, time to peak plasma concentration; $t_{1 / 2}$, elimination half-life.

after the breakfast test meal; there were no significant differences between the two treatment regimens in the primary endpoint. As observed with other GLP-1 peptide agonists, five patients did form antibodies to lixisenatide, and pharmacokinetic data were reported only for those individuals who were antibody-negative $(n=59)$ due to a potential interaction between anti-lixisenatide antibodies and the assay to determine lixisenatide plasma concentrations. In this study, the half-life of lixisenatide was 2.7-4.3 hours and was slightly longer in the groups that received twice-daily dosing.

In a two-way crossover study, 22 patients with type 2 diabetes were randomized to a single subcutaneous injection of lixisenatide $20 \mu \mathrm{g}$ or placebo. ${ }^{18}$ Two hours after the lixisenatide or placebo injection, patients received an intravenous bolus of glucose $0.3 \mathrm{~g} / \mathrm{kg}$ body weight over a period of 30 seconds. Lixisenatide enhanced the first-phase insulin response to intravenous glucose by more than six-fold and second-phase insulin response by approximately three-fold compared with placebo (Figure 2). In this study,

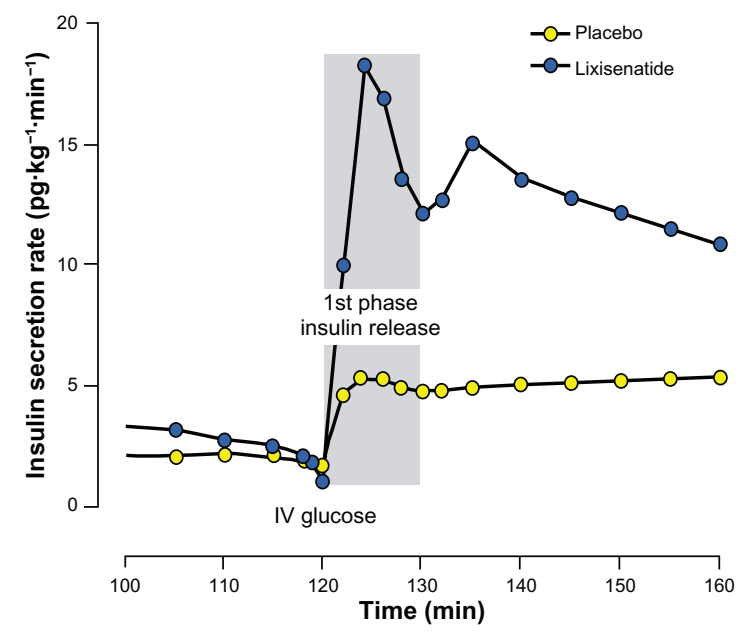

Figure 2 Mean insulin secretion rate after an intravenous glucose challenge following injection of lixisenatide $20 \mu \mathrm{g}$ or placebo. ${ }^{18}$

Note: Data compiled from ClinicalTrials.gov. lixisenatide did not affect glucagon suppression. Maximum plasma concentrations were achieved 2 hours after the single injection.

To determine the pharmacokinetics and safety of lixisenatide in patients with renal impairment, a single $5 \mu \mathrm{g}$ subcutaneous injection was administered to eight healthy subjects with normal renal function (creatinine clearance $>80 \mathrm{~mL} /$ minute), and eight each with mild (50-80 $\mathrm{mL} /$ minute), moderate $(30-50 \mathrm{~mL} /$ minute), or severe renal impairment $(<30 \mathrm{~mL} /$ minute, but not requiring dialysis). ${ }^{19} \mathrm{AUC}$ and $\mathrm{C}_{\max }$ values observed in patients with mild to moderate renal impairment did not differ significantly from those observed in healthy subjects. In patients with severe renal impairment, drug exposure was increased, suggesting that dosage adjustment may be required.

To characterize the dose-response effect of lixisenatide fully, a total of eight regimens $(5,10,20$, or $30 \mu \mathrm{g})$ each administered once daily or twice daily, were compared with placebo in a 13-week, randomized, placebo-controlled, parallel-group study of 542 patients with type 2 diabetes $\left(\mathrm{HbA}_{1 \mathrm{c}} \geq 7.0 \%\right.$ to $\left.<9.0 \%\right)$ who were inadequately controlled on metformin monotherapy. ${ }^{20}$ The lixisenatide $20 \mu \mathrm{g}$ and $30 \mu \mathrm{g}$ doses were administered in escalating doses during the first 4 weeks of the study, with the dose initiated at $10 \mu \mathrm{g}$ for 1 week and increased by $5 \mu \mathrm{g}$ per week up to the target dose. At week 13, statistically significant reductions in the primary endpoint (change in $\mathrm{HbA}_{1 \mathrm{c}}$ from baseline to endpoint) were observed for all lixisenatide treatment groups compared with placebo (all $P<0.01$ versus placebo). A dose-response relationship for $\mathrm{HbA}_{1 \mathrm{c}}$ level was observed for both the oncedaily and twice-daily lixisenatide dosing regimens. Mean $\mathrm{HbA}_{1 \mathrm{c}}$ reductions from the mildly hyperglycemic baseline $\mathrm{HbA}_{1 \mathrm{c}}$ of $7.6 \%$ were $0.47 \%, 0.50 \%, 0.69 \%$, and $0.76 \%$ for the once-daily lixisenatide regimens, and $0.65 \%, 0.78 \%$, $0.75 \%$ and $0.87 \%$ for the twice-daily regimens, respectively, compared with $0.18 \%$ for placebo (Figure 3). A target 


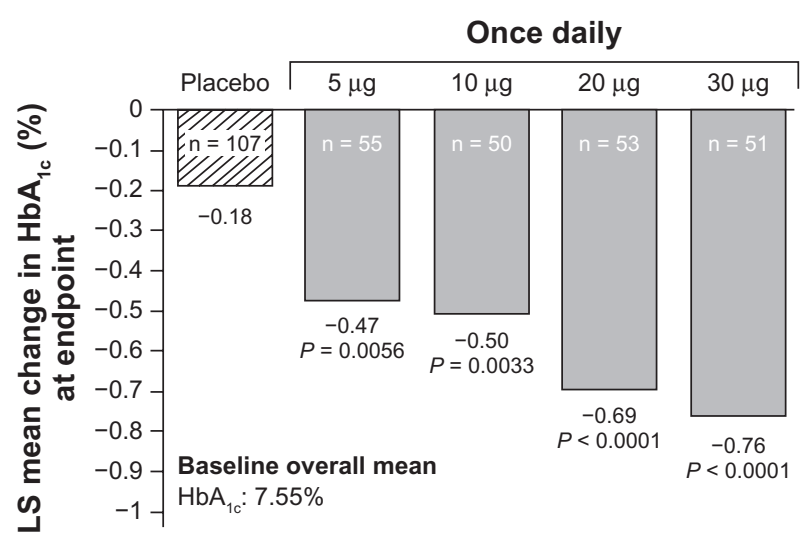

\section{Twice daily}

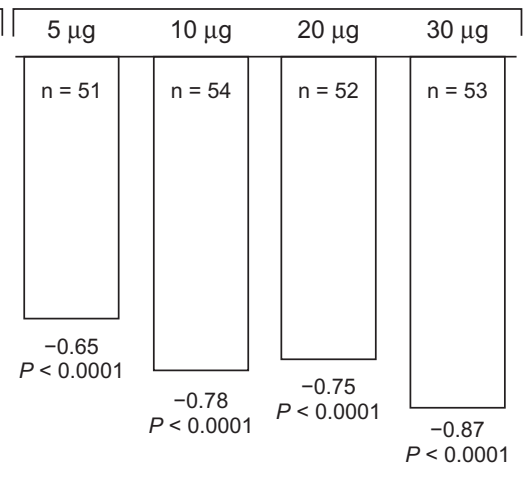

Figure 3 Least squares mean change in $\mathrm{HbA}_{\mathrm{lc}}$ after 13 weeks of treatment with lixisenatide once-daily or twice-daily according to dosage and regimen. ${ }^{20}$ Abbreviations: $\mathrm{HbA}_{\mathrm{Ic}}$, glycosylated hemoglobin; LS, least squares.

Note: Reproduced from Becker RH, Ruus P, Liu Y-H, Kapitza C. Restoration of insulin release with lixisenatide in patients with type 2 diabetes. Diabetologica. 20I0;53 Suppl I:S339, with permission of the publisher.

$\mathrm{HbA}_{1 \mathrm{c}}$ of $<7.0 \%$ at study end was achieved in $68 \%$ of patients receiving lixisenatide $20 \mu \mathrm{g}$ and $30 \mu \mathrm{g}$ once daily compared with $32 \%$ of patients receiving placebo $(P<0.0001)$. Statistically significant dose-dependent reductions from baseline in fasting and 2-hour postprandial plasma glucose were also observed. The improvements in glycemic control with lixisenatide were coupled with reductions in body weight, ie, $3.0 \mathrm{~kg}$ for lixisenatide $20 \mu \mathrm{g}$ compared with $1.9 \mathrm{~kg}$ for placebo (Figure 4). In this study, the once-daily and twice-daily regimens provided similar levels of efficacy, and doubling the daily dose in the twice-daily regimens did not provide relevant additional improvements in glycemic control over the once-daily regimens.

Lixisenatide has also been investigated in a 4-week trial in 150 patients with type 2 diabetes not achieving adequate glycemic control with metformin, using liraglutide as the active comparator. The primary endpoint was change from baseline in postprandial plasma glucose after a standardized breakfast. Although the trial has been completed, results have not yet been presented.

\section{Efficacy studies: the GETGOAL program}

The Phase III clinical trial program for lixisenatide began in 2008. Known as the GETGOAL program, it consisted of two parallel programs. The most advanced involved ten individual clinical trials to assess the efficacy and safety of lixisenatide in adult patients with type 2 diabetes treated with various oral antidiabetes agents or insulin. The program enrolled more than 4500 patients globally, the first results of which were presented in abstract form in 2010 (Table 2). The remaining trials are expected to complete in 2011. The second part of the program involved a combination of lixisenatide and the once-daily, long-acting insulin analog, insulin glargine.

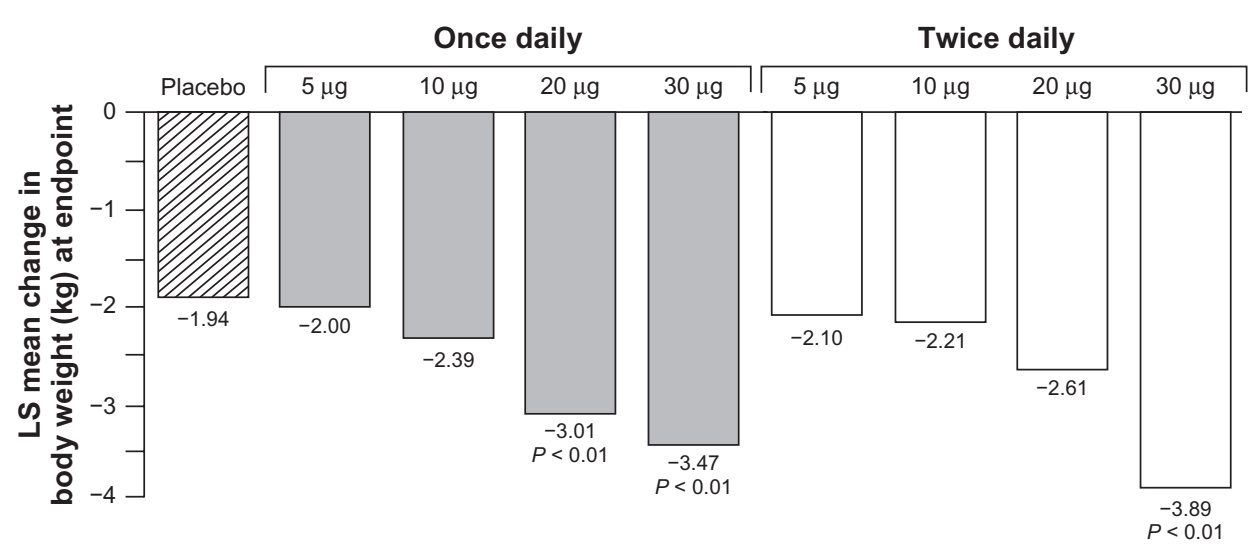

Figure 4 Least squares mean change in body weight after 13 weeks of treatment with lixisenatide once-daily or twice-daily according to dosage and regimen. ${ }^{20}$ Note: Reproduced from Becker RH, Ruus P, Liu Y-H, Kapitza C. Restoration of insulin release with lixisenatide in patients with type 2 diabetes. Diabetologica. 20I0;53 Suppl I:S339, with permission of the publisher.

Abbreviation: LS, least squares. 
Table 2 Summary of the GETGOAL Phase III clinical trial program with lixisenatide

\begin{tabular}{|c|c|c|c|c|c|c|}
\hline Trial & Comparator & Participants & $\begin{array}{l}\text { Duration } \\
\text { (weeks) }\end{array}$ & $\begin{array}{l}\text { Primary } \\
\text { outcome }\end{array}$ & $\begin{array}{l}\text { Secondary } \\
\text { outcome }\end{array}$ & Status \\
\hline $\begin{array}{l}\text { GETGOAL- } \\
\text { Mono }\end{array}$ & $\begin{array}{l}\text { Lixisenatide vs PCB } \\
\text { (I-step and 2-step } \\
\text { titration) }\end{array}$ & $\begin{array}{l}36 \mathrm{I} \text { adults previously } \\
\text { untreated with } \\
\text { antidiabetes agents }\end{array}$ & 12 & $\begin{array}{l}\text { Change in } \mathrm{HbA}_{\mathrm{lc}} \\
\text { from baseline }\end{array}$ & $\begin{array}{l}\text { Changes in body } \\
\text { weight, FPG, } \\
2 \text { hour-PPG }\end{array}$ & Completed \\
\hline GETGOAL-FI & $\begin{array}{l}\text { Lixisenatide + MET vs } \\
\text { PCB + MET (I-step } \\
\text { and 2-step titration) }\end{array}$ & $\begin{array}{l}450 \text { adults previously } \\
\text { treated with MET }\end{array}$ & 24 & $\begin{array}{l}\text { Change in } \mathrm{HbA}_{\mathrm{lc}} \\
\text { from baseline }\end{array}$ & $\begin{array}{l}\text { Changes in body } \\
\text { weight, FPG }\end{array}$ & Completed \\
\hline GETGOAL-S & $\begin{array}{l}\text { Lixisenatide }+\mathrm{SU} \\
\text { vs } \mathrm{PCB}+\mathrm{SU}\end{array}$ & $\begin{array}{l}859 \text { adults previously } \\
\text { treated with SU }\end{array}$ & 24 & $\begin{array}{l}\text { Change in } \mathrm{HbA}_{\mathrm{lc}} \\
\text { from baseline }\end{array}$ & $\begin{array}{l}\text { Changes in body weight, } \\
\text { FPG, } 2 \text { hour-PPG }\end{array}$ & Completed \\
\hline GETGOAL-L & $\begin{array}{l}\text { Lixisenatide }+ \text { basal } \\
\text { insulin vs } P C B+\text { basal } \\
\text { insulin }\end{array}$ & $\begin{array}{l}495 \text { adults previously } \\
\text { treated with basal } \\
\text { insulin }\end{array}$ & 24 & $\begin{array}{l}\text { Change in } \mathrm{HbA}_{\mathrm{lc}} \\
\text { from baseline }\end{array}$ & $\begin{array}{l}\text { Changes in body weight, } \\
\text { FPG, change from } \\
\text { baseline in insulin doses }\end{array}$ & Completed \\
\hline GETGOAL-P & $\begin{array}{l}\text { Lixisenatide + PIO vs } \\
\text { PCB + PIO }\end{array}$ & $\begin{array}{l}450 \text { adults previously } \\
\text { treated with PIO }\end{array}$ & 24 & $\begin{array}{l}\text { Change in } \mathrm{HbA}_{\mathrm{lc}} \\
\text { from baseline }\end{array}$ & $\begin{array}{l}\text { Changes in body } \\
\text { weight, FPG, fasting } \\
\text { plasma insulin }\end{array}$ & $\begin{array}{l}\text { Expected } \\
\text { completion } \\
\text { Q2 2011 }\end{array}$ \\
\hline GETGOAL-X & $\begin{array}{l}\text { Lixisenatide + MET vs } \\
\text { EXE + MET }\end{array}$ & $\begin{array}{l}634 \text { adults previously } \\
\text { treated with MET }\end{array}$ & 24 & $\begin{array}{l}\text { Noninferiority in } \\
\mathrm{HbA}_{\mathrm{Ic}} \text { reduction } \\
\text { from baseline }\end{array}$ & $\begin{array}{l}\text { Changes in body weight, } \\
\text { FPG, quality of life }\end{array}$ & Completed \\
\hline GETGOAL-M & $\begin{array}{l}\text { Lixisenatide (morning } \\
\text { or evening dose) + } \\
\text { MET vs PCB + MET }\end{array}$ & $\begin{array}{l}680 \text { adults previously } \\
\text { treated with MET }\end{array}$ & 24 & $\begin{array}{l}\text { Change in } \mathrm{HbA}_{\mathrm{lc}} \\
\text { from baseline }\end{array}$ & $\begin{array}{l}\text { Changes in body weight, } \\
\text { FPG, } 2 \text { hour-PPG }\end{array}$ & Completed \\
\hline $\begin{array}{l}\text { GETGOAL- } \\
\text { Mono JAPAN } \\
\text { LTS }\end{array}$ & $\begin{array}{l}\text { Open-label lixisenatide } \\
\text { (I- and 2-step titration) }\end{array}$ & $\begin{array}{l}66 \text { adults not treated } \\
\text { with antidiabetes } \\
\text { agents }\end{array}$ & 52 & Safety measures & $\begin{array}{l}\text { Changes in } \mathrm{HbA}_{\mathrm{lc}} \\
\text { and FPG from baseline }\end{array}$ & Completed \\
\hline $\begin{array}{l}\text { GETGOAL- } \\
\text { L-ASIA }\end{array}$ & $\begin{array}{l}\text { Lixisenatide }+ \text { basal } \\
\text { insulin vs PCB }+ \\
\text { basal insulin }\end{array}$ & $\begin{array}{l}3 \mathrm{II} \text { adults previously } \\
\text { treated with basal } \\
\text { insulin } \pm \mathrm{SU}\end{array}$ & 24 & $\begin{array}{l}\text { Change in } \mathrm{HbA}_{\mathrm{Ic}} \\
\text { from baseline }\end{array}$ & $\begin{array}{l}\text { Change from baseline } \\
\text { in body weight, FPG, } \\
\text { insulin doses }\end{array}$ & Completed \\
\hline $\begin{array}{l}\text { GETGOAL- } \\
\text { M-As China }\end{array}$ & $\begin{array}{l}\text { Lixisenatide }+\mathrm{MET} \pm \\
\mathrm{SU} \text { vs } \mathrm{PCB}+\mathrm{MET} \pm \mathrm{SU}\end{array}$ & $\begin{array}{l}380 \text { adults previously } \\
\text { treated with MET or } \\
\text { MET + SU }\end{array}$ & 24 & $\begin{array}{l}\text { Change in } \mathrm{HbA}_{\mathrm{lc}} \\
\text { from baseline }\end{array}$ & $\begin{array}{l}\text { Changes in body weight, } \\
\text { FPG, } 2 \text { hour-PPG }\end{array}$ & Ongoing \\
\hline
\end{tabular}

Notes: All the 24-week GETGOAL trials with the exception of GETGOAL-L-ASIA have a variable extension period; the GETGOAL-Mono JAPAN LTS trial has a 24-week extension period. Data sourced from the ClinicalTrials.gov website (http://clinicaltrials.gov/).

Abbreviations: EXE, exenatide; MET, metformin; PCB, placebo; PIO, pioglitazone; SU, sulfonylurea; FPG, fasting plasma glucose; PPG, postprandial glucose.

For all these trials, the once-daily lixisenatide $20 \mu \mathrm{g}$ dose was selected, because in previous trials it had demonstrated the best efficacy to tolerability ratio.

\section{GETGOAL-Mono}

The first results to be reported were those of the GETGOALMono trial. In this 12-week trial, 361 patients with type 2 diabetes $\left(\mathrm{HbA}_{1 \mathrm{c}} 7 \%-10 \%\right)$ not currently receiving antidiabetes agents were randomized to one of four once-daily treatment regimens, ie, 119 patients underwent a one-step titration with lixisenatide ( $10 \mu \mathrm{g}$ for 2 weeks then $20 \mu \mathrm{g}), 120$ underwent a two-step titration with lixisenatide $(10 \mu \mathrm{g}$ for 1 week, $15 \mu \mathrm{g}$ for 1 week then $20 \mu \mathrm{g}$ ), 61 underwent a one-step placebo titration, and 61 underwent a two-step placebo titration. ${ }^{21}$ The mean age of patients was 54 years and the mean duration of type 2 diabetes was 2.5 years. Both lixisenatide titration groups were associated with statistically significant improvements in $\mathrm{HbA}_{1 \mathrm{c}}$ compared with placebo $(P<0.0001$, Table 3$)$. In addition, more patients in the lixisenatide groups achieved $\mathrm{HbA}_{1 \mathrm{c}} \leq 6.5 \%$ (25.4\% one-step titration, 31.9\% two-step titration) and $<7.0 \%$ (46.5\% one-step titration, $52.2 \%$ two-step titration) compared with placebo $(26.8 \%$ and $12.5 \%$, respectively; $P<0.01)$. Lixisenatide was associated with significant improvements in both 2-hour postprandial and fasting plasma glucose compared with placebo, with a particularly pronounced effect on postprandial plasma glucose (Table 3). Decreases in body weight were observed in all groups.

\section{GETGOAL-X}

Results from several other GETGOAL studies have been unveiled by Sanofi-Aventis and Zealand Pharma and presented in abstract form at conferences in 2011. GETGOAL-X was the first head-to-head trial comparing lixisenatide with another GLP-1 agonist. In this randomized, open-label, 24-week trial, once-daily lixisenatide $20 \mu \mathrm{g}$ was compared with twicedaily exenatide $10 \mu \mathrm{g}$ as add-on therapy in 634 people not achieving glycemic control with metformin $\geq 1.5 \mathrm{~g} /$ day. ${ }^{22}$ Both groups received a stepwise increase in dose, up to a maximum daily dose of $20 \mu \mathrm{g}$. The mean age of the patients was 57 years, mean duration of type 2 diabetes was 7 years, 
Table 3 Mean baseline and I2-week changes in glycemic efficacy variables for 36I patients with type 2 diabetes randomized to one of four once-daily treatment regimens, ie, lixisenatide two-step titration ( $10 \mu \mathrm{g}$ for I week, I5 $\mu \mathrm{g}$ for I week then $20 \mu \mathrm{g} ; \mathrm{n}=120)$, lixisenatide one-step titration ( $10 \mu \mathrm{g}$ for 2 weeks then $20 \mu \mathrm{g} ; \mathrm{n}=1 \mathrm{I}$ ), placebo two-step titration $(\mathrm{n}=6 \mathrm{I})$, or placebo one-step titration $(\mathrm{n}=6 \mathrm{I})^{2 \mathrm{I}}$

\begin{tabular}{|c|c|c|c|c|}
\hline \multirow[t]{2}{*}{ Variable } & & \multirow[t]{2}{*}{ Placebo $(n=|2|)$} & \multicolumn{2}{|l|}{ Lixisenatide } \\
\hline & & & 2-step titration $(n=120)$ & I-step titration $(n=1 \mid 8)$ \\
\hline \multirow[t]{4}{*}{$\mathrm{HbA}_{\mathrm{Ic}}(\%)$} & Baseline & $8.07 \pm 0.92$ & $7.97 \pm 0.91$ & $8.06 \pm 0.85$ \\
\hline & Change from baseline & $-0.19 \pm 0.12$ & $-0.73 \pm 0.12$ & $-0.85 \pm 0.12$ \\
\hline & LS mean difference vs PCB & - & $-0.54 \pm 0.12$ & $-0.66 \pm 0.12$ \\
\hline & $95 \% \mathrm{Cl}$ & - & $(-0.79$ to -0.30$)$ & $(-0.90$ to -0.42$)$ \\
\hline 2-hour PPG & Baseline & $13.99 \pm 4.78$ & $14.67 \pm 3.78$ & $14.55 \pm 3.36$ \\
\hline \multirow[t]{3}{*}{$(\mathrm{mmol} / \mathrm{L})^{*}$} & Change from baseline & $-0.65 \pm 0.56$ & $-4.51 \pm 0.57$ & $-5.47 \pm 0.55$ \\
\hline & LS mean difference vs PCB & - & $-3.86 \pm 0.77$ & $-4.82 \pm 0.74$ \\
\hline & $95 \% \mathrm{Cl}$ & - & $(-5.38$ to -2.35$)$ & $(-6.29$ to -3.36$)$ \\
\hline Glucose excursion & Baseline & $4.72 \pm 3.65$ & $5.45 \pm 3.02$ & $5.25 \pm 2.89$ \\
\hline \multirow[t]{3}{*}{$(\mathrm{mmol} / \mathrm{L})^{*}$} & Change from baseline & $-0.67 \pm 0.45$ & $-3.77 \pm 0.45$ & $-4.36 \pm 0.44$ \\
\hline & LS mean difference vs PCB & - & $-3.10 \pm 0.61$ & $-3.69 \pm 0.59$ \\
\hline & $95 \% \mathrm{Cl}$ & - & $(-4.30$ to -1.90$)$ & $(-4.85$ to -2.53$)$ \\
\hline \multirow[t]{4}{*}{ FPG (mmol/L) } & Baseline & $8.91 \pm 2.17$ & $9.17 \pm 1.98$ & $9.02 \pm 1.97$ \\
\hline & Change from baseline & $+0.19 \pm 0.26$ & $-0.68 \pm 0.25$ & $-0.89 \pm 0.25$ \\
\hline & LS mean difference vs PCB & - & $-0.87 \pm 0.26$ & $-1.08 \pm 0.26$ \\
\hline & $95 \% \mathrm{Cl}$ & - & $(-1.37$ to -0.36$)$ & $(-1.59$ to -0.58$)$ \\
\hline
\end{tabular}

Notes: *At selected sites ( $n=62,60$, and 65 for the placebo, lixisenatide 2-step, and lixisenatide I-step groups, respectively); baseline data are mean \pm standard deviation; change from baseline (to week 12 or last observation carried forward) data are LS mean \pm standard error of the mean.

Abbreviations: $\mathrm{Cl}$, confidence interval; FPG, fasting plasma glucose; LS, least squares; PCB, placebo; PPG, postprandial plasma glucose.

and mean baseline $\mathrm{HbA}_{1 \mathrm{c}}$ was $8.0 \%$. Lixisenatide achieved its primary endpoint of noninferiority in $\mathrm{HbA}_{1 \mathrm{c}}$ reduction from baseline compared with exenatide using a predefined upper limit of $95 \%$ confidence interval (CI) $\leq 0.4$ : least squares mean difference $=0.17$ (95\% CI 0.03-0.30, Table 4). Improvements in mean fasting plasma glucose and the percentage of patients achieving $\mathrm{HbA}_{1 \mathrm{c}}<7.0 \%$ were comparable between groups (Table 4). Mean body weight significantly decreased from baseline, ie, $94.5 \mathrm{~kg}$ to $91.7 \mathrm{~kg}$ with lixisenatide and $96.7 \mathrm{~kg}$ to $92.9 \mathrm{~kg}$ with exenatide. Participants in this trial are also being followed in a variable extension of at least 52 weeks.

\section{GETGOAL-S}

GETGOAL-S was the largest trial in the clinical program and investigated the efficacy and safety of lixisenatide as add-on

Table 4 Preliminary results from the GETGOAL-X trial, a head-to-head comparison of lixisenatide and exenatide in patients not achieving adequate glycemic control with metformin $\geq 1.5 \mathrm{~g} / \mathrm{day}^{22}$

\begin{tabular}{|c|c|c|c|c|}
\hline \multicolumn{2}{|l|}{ Parameter } & \multirow{2}{*}{$\begin{array}{l}\text { Lixisenatide } \\
\mathrm{n}=3 \mathrm{II}\end{array}$} & \multicolumn{2}{|l|}{ Exenatide } \\
\hline \multicolumn{2}{|c|}{$\begin{array}{l}\text { Mean baseline and } 24 \text {-week changes in efficacy } \\
\text { parameters (ITT population) }\end{array}$} & & $\mathrm{n}=305$ & $\begin{array}{l}\text { LS mean difference } \\
(95 \% \mathrm{Cl})\end{array}$ \\
\hline \multirow[t]{2}{*}{$\mathrm{HbA}_{\mathrm{Ic}}(\%)$} & Baseline \pm SD & $7.97 \pm 0.82$ & $7.96 \pm 0.77$ & $0.17(0.03$ to 0.30$)$ \\
\hline & LS mean \pm SE change from baseline & $-0.79 \pm 0.05$ & $-0.96 \pm 0.05$ & \\
\hline \multirow[t]{2}{*}{ FPG $(\mathrm{mg} / \mathrm{dL})$} & Baseline \pm SD & $175 \pm 37$ & $|74 \pm 4|$ & 4.1 ( -0.9 to 9.4$)$ \\
\hline & LS mean \pm SE change from baseline & $-22.0 \pm 2.1$ & $-26.1 \pm 2.1$ & \\
\hline \multirow[t]{2}{*}{ Body weight (kg) } & Baseline \pm SD & $94.5 \pm 19.4$ & $96.7 \pm 22.8$ & $1.02(0.46$ to I.58) \\
\hline & LS mean \pm SE change from baseline & $-2.96 \pm 0.23$ & $-3.98 \pm 0.23$ & \\
\hline \multicolumn{2}{|c|}{ Safety parameters (safety population) } & $\mathrm{n}=318$ & $\mathrm{n}=316$ & $P$ value \\
\hline \multicolumn{2}{|c|}{ n (\%) patients with symptomatic hypoglycemia* } & $8(2.5 \%)$ & 25 (7.9\%) & $<0.05$ \\
\hline \multicolumn{2}{|c|}{ n hypoglycemic events } & 8 & 48 & \\
\hline \multicolumn{2}{|c|}{ n (\%) patients with nausea } & 78 (24.5\%) & III (35.1\%) & $<0.05$ \\
\hline \multicolumn{2}{|c|}{ n (\%) patients with diarrhea } & $33(10.4 \%)$ & $42(\mid 3.3 \%)$ & NS \\
\hline \multicolumn{2}{|c|}{ n (\%) patients with vomiting } & $32(10.1 \%)$ & $42(13.3 \%)$ & NS \\
\hline
\end{tabular}

Note: *Event with clinical symptoms with either plasma glucose $<60 \mathrm{mg} / \mathrm{dL}(3.3 \mathrm{mmol} / \mathrm{L})$ or prompt recovery after oral carbohydrate administration if no plasma glucose measurement was available.

Abbreviations: $\mathrm{Cl}$, confidence interval; $\mathrm{HbA}_{1 \mathrm{c}}$, glycosylated hemoglobin; FPG, fasting plasma glucose; ITT, intent-to-treat; LS, least squares; NS, not significant; SD, standard deviation; SE, standard error of the mean. 
therapy in patients not achieving glycemic control with a sulfonylurea, with or without metformin. GETGOAL-S was a randomized, double-blind, placebo-controlled study with a 24-week treatment period. ${ }^{23}$ In total, 859 patients were randomized to receive either lixisenatide or placebo in stepwise increasing doses, up to a maintenance dose of $20 \mu \mathrm{g}$ daily. The trial results have not yet been presented in abstract form, but a Sanofi-Aventis press release has reported that patients in the lixisenatide group experienced a significant reduction in $\mathrm{HbA}_{1 \mathrm{c}}$ levels, with a $-0.74 \%$ difference versus placebo $(P<0.0001)$ at week 24 . The drug was also associated with significant reductions in 2-hour postprandial $(P<0.0001)$ and fasting plasma glucose levels $(P<0.0001)$. Body weight was also significantly reduced $(P<0.0001)$ compared with patients receiving placebo.

\section{Combined lixisenatide and insulin}

In patients with type 2 diabetes, the progressive decline in beta cell function and increasing insulin resistance combined with an increased hepatic glucose output as a result of hypersecretion of glucagon leads to elevations in both fasting and postprandial glucose levels. Therefore, there is significant merit in the use of combination therapies to target these multiple pathophysiological defects. This has drawn attention to the possibility of using GLP-1 receptor agonists with basal insulin, the former agent targeting postprandial plasma glucose and the latter agent targeting fasting plasma glucose. Two trials in the GETGOAL program are evaluating this rationale.

\section{GETGOAL-L-ASIA}

GETGOAL-L-ASIA was the first study to evaluate lixisenatide in combination with a basal insulin. This 24-week, double-blind, placebo-controlled trial assessed the efficacy and safety of lixisenatide as add-on therapy in 311 Asian patients with type 2 diabetes not achieving glycemic control with basal insulin (with or without a sulfonylurea). ${ }^{24}$ Patients in the trial had a mean type 2 diabetes duration of 14 years, mean age of 58 years, body mass index of $25.3 \mathrm{~kg} / \mathrm{m}^{2}$, and a mean baseline $\mathrm{HbA}_{1 \mathrm{c}}$ of $8.53 \%$. Patients were randomized to add either lixisenatide $20 \mu \mathrm{g}$ once daily $(n=154)$ or placebo $(n=157)$ to their existing treatment regimen; approximately $60 \%$ of patients were taking insulin glargine as their basal insulin. The primary endpoint was change in $\mathrm{HbA}_{1 \mathrm{c}}$ from baseline to week 24. Results from the trial showed that lixisenatide once daily in combination with basal insulin significantly improved glycemic control, the addition of lixisenatide to basal insulin reducing $\mathrm{HbA}_{1 \mathrm{c}}$ levels by $0.9 \%$ versus placebo $(P<0.0001)$. Patients receiving lixisenatide were more likely to achieve an $\mathrm{HbA}_{1 \mathrm{c}}$ $\leq 6.5 \%$ and $<7.0 \%$ : $17.8 \%$ and $35.6 \%$ for lixisenatide, respectively, compared with $1.3 \%$ and $5.2 \%$, respectively, for placebo $(P<0.0001)$. Lixisenatide was also associated with significantly greater improvements in 2-hour postprandial plasma glucose.

\section{GETGOAL-L}

The second trial to investigate the benefits of lixisenatide in combination with basal insulin was GETGOAL-L, which randomized 495 patients not achieving adequate glycemic control on a combination of insulin glargine and metformin to add-on lixisenatide $20 \mu \mathrm{g}$ once daily or placebo for 24 weeks. ${ }^{25}$ In the lixisenatide-basal insulin combination trials, the first step after screening was to optimize insulin therapy to the point where the patient was not achieving any further reductions in $\mathrm{HbA}_{1 \mathrm{c}}$ or where hypoglycemia became the limiting factor. The patients were then randomized to one of the two treatment arms while continuing with maximally optimized glargine therapy for a further 6 months, with both lixisenatide and insulin glargine injected in the morning within 1 hour prior to breakfast. The results are expected to be presented at a medical congress in 2011, but a SanofiAventis press release has reported that the GETGOAL-L trial showed a significant reduction in $\mathrm{HbA}_{1 \mathrm{c}}$ levels $(P=0.0002)$ with lixisenatide, without a significant increase in the incidence of symptomatic hypoglycemia $(P=0.14)$ versus placebo. In addition, patients treated with lixisenatide had significantly improved postprandial plasma glucose after a test meal $(P<0.0001)$ and a significant reduction in body weight $(P<0.0001)$. These results confirm those of GETGOAL-L-Asia, this time in a broader population including both Caucasian and Asian patients.

\section{Additional clinical efficacy trials Lixisenatide versus sitagliptin}

In addition to the GETGOAL program, two other Phase III trials with lixisenatide were listed on the ClinicalTrials.gov registry. The first was a 24 -week Phase III study comparing lixisenatide with sitagliptin as add-on therapy in 300 adults younger than 50 years of age, with a body mass index $\geq 30 \mathrm{~kg} / \mathrm{m}^{2}$ and not achieving adequate glycemic control with metformin. The primary outcome in this double-blind, double-dummy trial was the percentage of patients with $\mathrm{HbA}_{1 \mathrm{c}}$ values $<7 \%$ and a weight loss of at least $5 \%$ of baseline body weight. The trial has been completed, but results not yet presented. 


\section{Cardiovascular outcome trial}

The second Phase III trial was ELIXA (Evaluation of Cardiovascular Outcomes in Patients With Type 2 Diabetes After Acute Coronary Syndrome During Treatment With AVE0010 [lixisenatide]). This large cardiovascular outcome trial recruited patients with type 2 diabetes who had experienced an acute coronary syndrome event (ie, ST segment elevation myocardial infarction, non-ST segment elevation myocardial infarction, or unstable angina) with a target sample size of 6000 . Patients were randomized to once-daily lixisenatide or placebo, with a median estimated follow-up period of approximately 2 years. The primary endpoint was time to the first occurrence of a primary cardiovascular event, ie, cardiovascular death, nonfatal myocardial infarction, nonfatal stroke, and hospitalization for unstable angina. This trial meets the new US Food and Drug Administration guidance introduced in 2008, which requires that manufacturers developing new drugs for type 2 diabetes provide evidence that the therapy will not increase the risk of cardiovascular events. Results from this trial are not expected until 2013.

\section{Safety and tolerability}

As a result of the lack of published data, safety and tolerability information on lixisenatide is currently limited, but the following information provides a summary of the published findings.

\section{Treatment-emergent adverse events}

In the GETGOAL-Mono trial there was only one $(0.4 \%)$ serious treatment-emergent adverse event in a lixisenatide-treated patient (two-step titration group) compared with five (4.1\%) in the placebo group. ${ }^{21}$ Nine patients discontinued due to a treatment-emergent adverse event, ie, five (4.2\%) in the lixisenatide two-step group, three (2.5\%) in the lixisenatide one-step group, and one $(0.8 \%)$ in the placebo group.

In the GETGOAL-X trial, the proportion of patients with adverse events was generally comparable between the lixisenatide and exenatide groups. ${ }^{22}$ There were 33 (10.4\%) patient discontinuations due to adverse events (mainly gastrointestinal) in the lixisenatide group and 41 (13.0\%) with exenatide. A greater proportion of patients in the lixisenatide group tolerated the target dose of $20 \mu \mathrm{g} / \mathrm{day}$ ( $93 \%$ versus $83 \%$ with exenatide).

In GETGOAL-L-ASIA, $86 \%$ of patients on lixisenatide completed the trial compared with $92 \%$ of placebo patients. ${ }^{24}$ Serious treatment-emergent adverse events occurred in $10(6.5 \%)$ lixisenatide patients and nine (5.7\%) placebo patients. Fourteen (9.1\%) patients in the lixisenatide group discontinued due to adverse events compared with five $(3.2 \%)$ in the placebo group, mostly due to gastrointestinal events.

\section{Gastrointestinal adverse events}

The most frequent adverse events associated with lixisenatide include transient dose-dependent nausea, diarrhea, and vomiting. ${ }^{20-22,24}$ In the GETGOAL-Mono trial, nausea was the most frequent (24.2\% for lixisenatide two-step, $20.2 \%$ for lixisenatide one-step, $4.1 \%$ for placebo) ${ }^{21}$ In the GETGOAL-X trial, overall gastrointestinal tolerability appeared better for lixisenatide versus exenatide, with fewer cases of nausea and vomiting (Table 4). ${ }^{22}$ In GETGOAL-L-ASIA, nausea and vomiting were reported in $39.6 \%$ and $18.2 \%$ of the patients, respectively, in the lixisenatide group and $4.5 \%$ and $1.9 \%$ of patients, respectively, in the placebo group. ${ }^{24}$

\section{Hypoglycemia}

Similar to other GLP-1 agonists, lixisenatide only stimulates insulin secretion and suppresses glucagon secretion in the presence of elevated blood glucose and, as a result, the risk of hypoglycemia should be reduced compared with some other antidiabetes therapies. In the GETGOAL-Mono trial, symptomatic hypoglycemia occurred in three patients $(2.5 \%)$ in the lixisenatide two-step group, one $(0.8 \%)$ in the lixisenatide one-step group, and two (1.6\%) in the placebo group, with no cases of severe hypoglycemia. ${ }^{21}$ In GETGOAL-X, initial results showed that significantly fewer people with type 2 diabetes treated with lixisenatide reported symptomatic hypoglycemia versus patients treated with exenatide, ie, eight (2.5\%) versus 25 (7.9\%), respectively; $P<0.05$ (Table 4). ${ }^{22} \mathrm{~A}$ total of eight hypoglycemic events were reported in patients receiving lixisenatide compared with 48 events in patients receiving exenatide. No severe episodes were reported. With other GLP-1 agonists, the highest incidence of hypoglycemic events has been observed when they are used in combination with a sulfonylurea. Preliminary results from the GETGOAL-S trial report that lixisenatide as add-on therapy to a sulfonylurea did not significantly increase the risk of symptomatic hypoglycemia compared with placebo. ${ }^{23}$ In the GETGOAL-L-ASIA trial, $42.9 \%$ of patients in the lixisenatide group reported symptomatic hypoglycemia compared with $23.6 \%$ in the placebo group. ${ }^{24}$ However, in patients not receiving a sulfonylurea, the addition of lixisenatide to a basal insulin resulted in a hypoglycemia rate of $31.8 \%$ in lixisenatide patients and $28.3 \%$ in placebo patients. There were no cases of severe hypoglycemia. 


\section{Antibody formation}

Antibody formation occurs in a significant number of patients treated with GLP-1 receptor agonists. ${ }^{26}$ It is possible that exendin-4-based compounds, which include exenatide and lixisenatide, may result in greater antibody formation, possibly because of a lower homology with native GLP-1. However, only one study to date has reported antibody data with lixisenatide, and the relevance of antibody formation remains unclear.

\section{Discussion}

The clinical effectiveness of lixisenatide has been evaluated in the GETGOAL program. This was designed to assess the efficacy and safety of lixisenatide across the spectrum of type 2 diabetes care, both as monotherapy and in combination with commonly used antidiabetes agents, in a series of randomized, controlled trials in more than 4500 people (Table 2). The first Phase III results with lixisenatide have been presented and demonstrate that it exhibits the properties expected of a GLP-1 receptor agonist in terms of improving glycemic control while reducing or eliminating the risk of hypoglycemia and weight gain. If approved, lixisenatide would be the third GLP-1 receptor agonist to enter the market after exenatide and liraglutide, with which it would have to compete.

In a head-to-head trial, initial results showed noninferior $\mathrm{HbA}_{1 \mathrm{c}}$ reduction and weight loss with once-daily lixisenatide compared with twice-daily exenatide, whilst delivering a better safety and tolerability profile. ${ }^{22}$ However, in the Liraglutide Effect and Action in Diabetes (LEAD)-6 trial, a head-to-head comparison of subcutaneous liraglutide $1.8 \mathrm{mg}$ once daily and exenatide $10 \mu \mathrm{g}$ twice daily, liraglutide was associated with a significantly greater reduction in $\mathrm{HbA}_{1 \mathrm{c}}$ compared with exenatide $\left(1.12 \%\right.$ versus $0.79 \%$, respectively) ${ }^{27}$ It will not be known how lixisenatide compares with liraglutide until the results of the head-to-head trial with liraglutide become available. A key differentiating factor is likely to be the effect of lixisenatide on postprandial plasma glucose. Although liraglutide targets both fasting and postprandial plasma glucose, significantly greater reductions in fasting plasma glucose are achieved, reflecting the action of liraglutide as a 24-hour GLP-1 agonist. In contrast, lixisenatide achieves greater reductions in postprandial plasma glucose as a result of its more rapid time-action profile, while maintaining the ability to be dosed once daily.

The dosing regime is an important consideration for any new GLP-1 receptor agonist. With lixisenatide, dose-response relationships were demonstrated for both the once-daily and twice-daily regimens, with similar efficacy levels. ${ }^{20}$ The once-daily $20 \mu \mathrm{g}$ dose of lixisenatide demonstrated the best efficacy-to-tolerability ratio and was selected for the GETGOAL program. The convenience of a once-daily dosing regimen is likely to be preferred by patients and would allow lixisenatide to compete with both twice-daily exenatide and once-daily liraglutide.

An important factor in the appeal of liraglutide and exenatide is the weight loss seen in many patients, and lixisenatide seems to produce similar results. The recent release of preliminary GETGOAL-S results, although not yet published in abstract form, indicate that lixisenatide as add-on to a sulfonylurea was associated with a significant decrease in body weight $(P<0.0001)$ compared with patients receiving placebo as add-on to a sulfonylurea. ${ }^{23}$

A pronounced effect of lixisenatide on postprandial plasma glucose in addition to a tendency for weight loss has led to investigation of the combined effects of lixisenatide and long-acting insulins in patients with type 2 diabetes. There is a good rationale for such a combination, with one targeting postprandial and the other fasting plasma glucose, providing additive effects on $\mathrm{HbA}_{1 \mathrm{c}}$, and one associated with weight loss and the other with a degree of weight gain. In addition, both GLP-1 receptor agonists and insulin analogs, such as insulin glargine, exhibit a protective function on beta cells, suggesting that the two agents in combination might represent a new therapeutic option for preservation of beta cell mass in patients with type 2 diabetes. Recent results with exenatide have demonstrated the feasibility of such an approach. In a 30-week study, 261 adults with type 2 diabetes who were receiving insulin glargine alone or in combination with metformin and/or pioglitazone were randomized to exenatide or placebo while continuing to optimize their insulin treatment. ${ }^{28}$ Patients had an average type 2 diabetes duration of 12 years, mean $\mathrm{HbA}_{1 \mathrm{c}} 8.3 \%-8.5 \%$, and were receiving an average insulin dose of 47-50 U/day. At the end of the study, mean $\mathrm{HbA}_{1 \mathrm{c}}$ had decreased by $1.74 \%$ with exenatide and $1.04 \%$ with placebo (between-group difference, $-0.69 \%$ [95\% CI, $-0.93 \%$ to $-0.46 \%$ ]; $P<0.001$ ). The exenatide treatment group also experienced other benefits, including a weight decrease of $1.8 \mathrm{~kg}$ compared with a weight increase of $1.0 \mathrm{~kg}$ with placebo, and an average increase in insulin dose of $13 \mathrm{U} /$ day with exenatide compared with $20 \mathrm{U} /$ day for placebo. The estimated rate of minor hypoglycemia was similar between the groups.

The findings confirm the rationale for combining the complementary effects of a GLP-1 receptor agonist with a basal insulin and have paved the way for similar trials with lixisenatide. In addition, preclinical studies have shown that beta cells treated with a combination of lixisenatide and 
insulin glargine are protected against cytokine-induced and free fatty acid-induced apoptosis, with additive benefits for the two agents in combination compared with either alone. ${ }^{16}$ The findings suggest that a combination of a GLP-1 receptor agonist and insulin glargine might represent an effective strategy for preserving beta cell mass in patients with type 2 diabetes and potentially could alter disease progression. Phase III clinical trials for the lixisenatide and insulin glargine combination have been completed, with preliminary results showing an approximately $0.9 \%$ reduction in $\mathrm{HbA}_{1 \mathrm{c}}$ on top of basal insulin. ${ }^{24,25}$

The currently available data show that lixisenatide is well tolerated. The GLP-1 receptor represents an established therapeutic target in type 2 diabetes, with agonists of this receptor demonstrating improved glucose tolerance alongside a low risk of hypoglycemia, beneficial weight loss, and the potential to modify disease progression. Early results with lixisenatide look promising, but data from the GETGOAL program are only just beginning to appear, and before any firm conclusions can be made, must be published in peer-reviewed journals. If results are positive, lixisenatide will be the third GLP-1 receptor agonist to enter the market. The factor that may distinguish it from exenatide and liraglutide is its strong postprandial effect. This property may prove beneficial in patients with mildly elevated $\mathrm{HbA}_{1 \mathrm{c}}$, in whom a therapeutic response is difficult to achieve with many existing antidiabetes therapies, as well as for use in combination with a basal insulin, such as insulin glargine, to achieve better glycemic control and minimize weight gain.

\section{Acknowledgments}

AHB received no personal compensation for writing this review, but has received honoraria for lectures and advisory work from relevant companies including Sanofi-Aventis, Eli Lilly, Novo Nordisk, and Roche.

\section{Disclosure}

The author reports no conflicts of interest in this work.

\section{References}

1. Danaei G, Finucane MM, Lu Y, et al. National, regional, and global trends in fasting plasma glucose and diabetes prevalence since 1980: Systematic analysis of health examination surveys and epidemiological studies with 370 country-years and 2.7 million participants. Lancet. 2011;378:31-40.

2. Department of Health. Turning the corner: Improving diabetes care. 2006. Available from: http://www.dh.gov.uk/prod_consum_dh/groups/ dh_digitalassets/@dh/@en/documents/digitalasset/dh_4136011.pdf. Accessed August 11, 2011.
3. International Diabetes Federation. Diabetes Atlas, 4th Edition. 2009. Available from: http://www.diabetesatlas.org/content/europe. Accessed August 11, 2011.

4. National Health Service. The Information Centre. Prevalence. Quality and outcomes framework (QOF) for April 2009 - March 2010, England. Available from: http://www.ic.nhs.uk/webfiles/QOF/2009-10/ Prevalence\%20tables/QOF0910_National_Prevalence.xls. Accessed August 11, 2011.

5. Drucker DJ, Nauck MA. The incretin system: Glucagon-like peptide-1 receptor agonists and dipeptidyl peptidase- 4 inhibitors in type 2 diabetes. Lancet. 2006;368:1696-1705.

6. National Institute for Health and Clinical Excellence. Type 2 diabetes: The management of type 2 diabetes. NICE clinical guideline 87 . May, 2009. Available from: http://www.nice.org.uk/nicemedia/pdf/ CG87 NICEGuideline.pdf. Accessed August 11, 2011.

7. Nathan DM, Buse JB, Davidson MB, et al. American Diabetes Association, European Association for the Study of Diabetes. Medical management of hyperglycaemia in type 2 diabetes mellitus: A consensus algorithm for the initiation and adjustment of therapy: a consensus statement from the American Diabetes Association and the European Association for the Study of Diabetes. Diabetologia. 2009;52:17-30.

8. Nathan DM, Buse JB, Davidson MB, et al; American Diabetes Association, European Association for Study of Diabetes. Medical management of hyperglycemia in type 2 diabetes: A consensus algorithm for the initiation and adjustment of therapy: a consensus statement of the American Diabetes Association and the European Association for the Study of Diabetes. Diabetes Care. 2009;32:193-203.

9. Deacon CF. Therapeutic strategies based on glucagon-like peptide 1 . Diabetes. 1994;53:2181-2189.

10. Thorkildsen C, Neve S, Larsen BD, Meier E, Pedersen JS. Glucagon-like peptide 1 receptor agonist ZP10 A increases insulin mRNA expression and prevents diabetic progression in $\mathrm{db} / \mathrm{db}$ mice. J Pharmacol Exp Ther. 2003;307:490-496.

11. Werner U, Haschke H, Herling AW, Kramer W. Pharmacological profile of lixisenatide: A new GLP-1 receptor agonist for the treatment of type 2 diabetes. Regul Pept. 2010;164:58-64.

12. Haschke G, Haag-Diergarten S, Werner U, Kramer W, Herling AW. The GLP-1 receptor agonist AVE0010 preserves beta cell function and insulin secretion after a 6 week treatment in male obese Zucker diabetic fatty rats an isolated perfused pancreas study. Diabetologia. 2006;49:400-401.

13. Moore MC, Werner U, Smith MS, Rodewald TD, Cherrington AD. Effect of the glucagon-like peptide-1 receptor agonist AVE0010 on postprandial hepatic glucose metabolism in the conscious dog. Diabetologia. 2007;50:S242.

14. Werner U, Gerlach M, Hofmann M, Herling AW. Treatment of obese Zucker diabetic fatty rats with novel GLP-1 receptor agonist AVE0010 improves oral glucose tolerance and glycaemic control without risk of hypoglycaemia. Diabetologia. 2006;49 Suppl 1:398-399.

15. Werner U, Vandewalle B, Kerr Conte J, Pattou F, Pruniaux M, Herling AW. The GLP-1 receptor agonist AVE0010 improves GSIS, prevents lipotoxicity-induced insulin depletion and preserves $\beta$-cell function in human pancreatic islets. Diabetes. 2008;57:3-4.

16. Tews D, Werner U, Eckel J. Enhanced protection against cytokine- and fatty acid-induced apoptosis in pancreatic beta cells by combined treatment with glucagon-like peptide-1 receptor agonists and insulin analogues. Horm Metab Res. 2008;40:172-180.

17. Distiller LA, Ruus P; on behalf of the ACT6011 Study Group. Pharmacokinetics and pharmacodynamics of a new GLP-1 agonist AVE0010 in type 2 diabetes patients. Diabetes. 2008;57 Suppl 1:A154-155.

18. Becker RH, Ruus P, Liu Y-H, Kapitza C. Restoration of insulin release with lixisenatide in patients with type 2 diabetes. Diabetologica. 2010;53 Suppl 1:S339.

19. Liu Y-H, Ruus P. Pharmacokinetics and safety of the GLP-1 agonist AVE0010 in patients with renal impairment. Abstract 557-P presented at the 69th Scientific Sessions of the American Diabetes Association, June 5-9, 2009, New Orleans, LA. 
20. Ratner RE, Rosenstock J, Boka G; DRI6012 Study Investigators. Dosedependent effects of the once-daily GLP-1 receptor agonist lixisenatide in patients with type 2 diabetes inadequately controlled with metformin: A randomized, double-blind, placebo-controlled trial. Diabet Med. 2010;27:1024-1032.

21. Gerich JE, Fonseca VA, Alvardo-Ruiz R, et al. Monotherapy with GLP-1 receptor agonist, lixisenatide, significantly improves glycaemic control in type 2 diabetic patients. Diabetologia. 2010;53 Suppl 1:S330.

22. Rosenstock J, Raccah D, Koranyi L, et al. Efficacy and safety of lixisenatide once-daily vs exenatide twice-daily in type $2 \mathrm{DM}$ inadequately controlled on metformin (GetGoal-X). Abstract 0033-LB presented at the 71st Scientific Sessions of the American Diabetes Association, June 24-28, 2011, San Diego, CA.

23. Sanofi-Aventis press release, 12 April 2011. Lixisenatide significantly reduces $\mathrm{HbA}_{1 \mathrm{c}}$ without increasing hypoglycemia in patients uncontrolled on sulfonylureas (GETGOAL-S). Available from: http://en.sanofi-aventis.com/binaries/20110412_LIXI_GETGOAL_S_EN_tcm28-31652. pdf. Accessed August 11, 2011.

24. Seino Y, Min K, Niemoeller E, Takami A. Lixisenatide significantly improves glycemic control in Asian patients with T2DM insufficiently controlled on basal insulin \pm SU. Abstract 0278-OR presented at the 71st Scientific Sessions of the American Diabetes Association, June 24-28, 2011, San Diego, CA.
25. Sanofi-Aventis press release, 31 May 2011. Sanofi GetGoal program on Lyxumia $^{\circledR}$, as an add-on to basal insulin, shows significant positive phase III results. Available from: http://en.sanofi.com/binaries/20110531 LYXUMIA_en_tcm28-32746.pdf. Accessed August 11, 2011.

26. Buse JB, Garber A, Rosenstock J, et al. Liraglutide treatment is associated with a low frequency and magnitude of antibody formation with no apparent impact on glycemic response or increased frequency of adverse events: Results from the Liraglutide Effect and Action in Diabetes (LEAD) trials. J Clin Endocrinol Metab. 2011;96:1695-1702.

27. Buse JB, Rosenstock J, Sesti G, et al; LEAD-6 Study Group. Liraglutide once a day versus exenatide twice a day for type 2 diabetes: A 26-week randomised, parallel-group, multinational, open-label trial (LEAD-6). Lancet. 2009;374:39-47.

28. Buse JB, Bergenstal RM, Glass LC, et al. Use of twice-daily exenatide in basal insulin-treated patients with type 2 diabetes: A randomized, controlled trial. Ann Intern Med. 2011;154:103-112.

\section{Core Evidence}

\section{Publish your work in this journal}

Core Evidence is an international, peer-reviewed open-access journal evaluating the evidence underlying the potential place in therapy of drugs throughout their development lifecycle from preclinical to postlaunch. The focus of each review is to evaluate the case for a new drug or class in outcome terms in specific indications and patient groups.

\section{Dovepress}

The manuscript management system is completely online and includes a very quick and fair peer-review system, which is all easy to use. Visit http://www.dovepress.com/testimonials.php to read real quotes from published authors. 